ACTA UNIVERSITATIS WRATISLAVIENSIS

No 4069

Studia nad Autorytaryzmem i Totalitaryzmem 43, nr 2

Wrocław 2021

https://doi.org/10.19195/2300-7249.43.2.14

WIOLETTA JEDLECKA

ORCID: 0000-0002-0542-9303

Uniwersytet Wrocławski

wioletta.jedlecka@uwr.edu.pl

\title{
Szpital psychiatryczny jako przykład instytucji totalnej
}

Slowa kluczowe: instytucja totalna, szpital psychiatryczny, „społeczność terapeutyczna”.

\section{PSYCHIATRIC HOSPITAL AS AN EXAMPLE OF A TOTAL INSTITUTION}

\section{Abstract}

The aim of this article is attempting to answer the question whether the psychiatric hospital can still be considered as a total institution. The concept of a psychiatric hospital as a total institution was formulated by Erving Goffman. In this type of facility, the personnel has full control over the patient, their time, private life, and mobility. However, a psychiatric hospital is also a special place. Is this type of hospital still a total institution? Is it not better now to call it a quasi-total institution?

Keywords: total institution, psychiatric hospital, "therapeutic community".

Celem niniejszego tekstu jest próba odpowiedzi na pytanie, czy instytucja, jaką jest szpital psychiatryczny, wciąż ma cechy instytucji totalnej w rozumieniu przyjętym przez Ervinga Goffmana. Czy współcześnie podejmowane w tego rodzaju szpitalach formy i rodzaje terapii mają wpływ na zmniejszenie uciążliwości związanej z hospitalizacją osób z zaburzeniami psychicznymi?

\section{Charakterystyka instytucji totalnej}

Erving Goffman wychodzi z założenia, że każda instytucja społeczna charakteryzuje się tendencją do zawładnięcia w jakimś stopniu czasem i zainteresowaniami 
swych członków, usiłuje też wywierać określony wpływ na ich postawy i zachowania. Należy pamiętać, że w społeczeństwie funkcjonują rozliczne instytucje o bardzo zróżnicowanym stopniu absorbowania swych członków i podporządkowania ich określonym podstawowym celom. Są wśród nich takie, które zmierzają do wytworzenia wyraźnych i trudno przekraczalnych barier w sferze stosunków społecznych miedzy członkami danej instytucji a światem zewnętrznym, na który składa się globalny system instytucji. Każda z takich instytucji, jak stwierdza Goffman, jest „hybrydą” społeczną, częścią społeczności rezydencjalnej i organizacji formalnej. Z tego właśnie powodu stanowią one przedmiot specjalnego zainteresowania socjologicznego. W społeczeństwie obecne są instytucje przymusowe powołane do „odmieniania ludzi”. Każda z nich to eksperyment świadczący o tym, co można uczynić z człowiekiem ${ }^{1}$. Prawzorem oraz poniekąd typem idealnym instytucji totalnej jest panoptikon, czyli wielofunkcyjny budynek służący nadzorowaniu ludzi (inspection house), zaprojektowany przez Jeremy'ego Benthama.

Instytucja totalna to taka, która stwarza dla osób z nią związanych rodzaj odrębnego świata, odseparowanego od reszty społeczeństwa i rządzącego się własnymi regułami. Cechy instytucji totalnej to: ścisła hierarchizacja statusów, formalizm, podział na personel i podwładnych, dehumanizacja, brak podmiotowości w stosunkach międzyludzkich oraz orientacja na wykonywanie zadań, a nie na człowieka ${ }^{2}$. Wskazuje się ponadto, że instytucje totalne są zakładami przymusowego przekształcania osobowości. Jak pisze Goffman: „każda z nich swoiście eksperymentuje na naturze, zwykle brutalnie, aby wykazać, co może uczynić z ludzkim »Ja«". Każdy człowiek, który zaczyna funkcjonowanie w instytucji totalnej, stara się przystosować do panujących w niej warunków. Te należą do uciążliwych, ale istnieją sposoby, by stawić im czoła. Poznanie i wyjaśnienie społecznych uwarunkowań zachowań ludzi w instytucji totalnej pozwala efektywniej organizować i planować działania, rozwiązywać problemy wynikające z niedostosowania zachowań do wymogów i ograniczeń instytucjonalnych oraz eliminować dysfunkcje w instytucjach (na przykład konflikty spowodowane doborem środków do celów, dysfunkcje w systemie komunikacji interpersonalnej) ${ }^{3}$. Instytucje totalne można uznać za przykład wyrafinowanych biurokracji. Złożone i surowe procedury obowiązują tu wszystkich ${ }^{4}$. Instytucje tego typu mają tendencję do zamykania się w obrębie własnych zadań i problemów, co oznacza, że zmierzają do stworzenia

${ }^{1}$ E. Goffman, Charakterystyka instytucji totalnych, [w:] Elementy teorii socjologicznych, red. W. Derczyński, A. Jasińska-Kania, J. Szacki, Warszawa 1975, s. 150-151.

2 M. Sobkowiak, Przemoc instytucjonalna $w$ jednostkach organizacyjnych pomocy społecznej, Szczecin 2012, s. 8.

${ }^{3}$ A. Baranowska, Proces ksztaltowania się tożsamości instytucji totalnej na przykładzie żotnierzy — mieszkańców obozu Babilon w Iraku, [w:] Tożsamość społeczna grup dyspozycyjnych, red. J. Maciejewski, W. Nowosielski, Wrocław 2009, s. 30.

${ }^{4}$ I. Fudali, Instytucje totalne - jak myśla instytucje w zglobalizowanym spoleczeństwie, „Drohiczyński Przegląd Naukowy, Wielokulturowe Studia Drohiczyńskiego Towarzystwa Naukowego" 2017, nr 9, s. 110. 
swoim członkom jak gdyby odrębnego świata. Zgodnie z regułami biurokracji działają według narzuconego regulaminu i planu. Plan jest wykonywany przez podwładnych, nadzorowanych przez personel (strażników, nadzorców), a każda planowana czynność i nadzorców, i podwładnych stanowi część zadania, jakie wykonuje dana instytucja. Nadrzędność zaplanowanych zadań nad jednostkowymi potrzebami, biurokratyczna procedura ich realizacji oraz oceny wyników prowadzi zdaniem Goffmana do ujednolicenia tożsamości członków instytucji poprzez upodobnienie ich wyglądu zewnętrznego, ograniczenia w zakresie posiadania rzeczy osobistych, poddanie ścisłej dyscyplinie określonej przez regulamin, podporzadkowanie personelowi. W ten sposób instytucja totalna staje się ,społecznym mikrokosmosem narzuconym przez hegemonię i hierarchiczny porządek" ${ }^{\prime 5}$. Życie mieszkańców instytucji totalnych toczy się zatem w jednym i tym samym miejscu. Podlegają oni tej samej, jedynej władzy, są traktowani w jednakowy sposób, a ich zadania są ściśle zaplanowane. Czynności, które wykonują, mają charakter przymusowy i stanowią część jednego ogólnego planu ${ }^{6}$. Produktem ubocznym instytucji totalnych jest zjawisko znane jako „drugie życie”, definiowane jako wytworzona spontanicznie organizacja nieformalna, która „porządkuje codzienne życie poza układami sformalizowanymi i [...] uzupełnia i wypełnia luki w organizacji formalnej”. Do zjawisk „drugiego życia” zaliczamy obecność w obrębie instytucji różnych grup nieformalnych, takich jak kliki czy koterie, oraz organizowanie nieformalnych rytuałów i zachowań symbolicznych, do których należą fala w wojsku czy grypsera w zakładach poprawczych i więzieniach. Grupy nieformalne przeradzają się często $\mathrm{w}$ subkultury, przekraczające ramy pojedynczych instytucji, a wspólne i typowe dla szerszych układów, na przykład sieci instytucji pewnego typu, obejmujących szkoły, szpitale itp. ${ }^{7}$

Zdaniem Łukasza Posłusznego Goffmanowska koncepcja instytucji totalnych stępiła się i dzisiaj rodzi więcej pytań niż udziela odpowiedzi. Z perspektywy kilkudziesięciu lat od wydania Asylums wokół pracy Goffmana urosło wiele nieporozumień, a definicja stała się rozmyta i niejasna. To umożliwiło używanie jej do opisu nieomal każdej instytucji społecznej, co rodzi oczywiste niebezpieczeństwa. Cytowany autor zauważa, że organizacje mogą odznaczać się pewnym stopniem totalizacji, ale nie czyni ich to instytucjami totalnymi. Dlatego sugeruje, aby w przypadkach granicznych mówić raczej o totalizmie organizacji. Pozwoli to - przy wykorzystaniu pojęcia izolacyjności, przenikalności, zachłanności itp. - zwrócić uwagę na kierunki przeobrażania się instytucji społecznych czy sprawdzić użyteczność tych kategorii w stosunku do nieoczywistych fenomenów, jak na przykład fawele. Analogicznie, organizacje o bardzo niskim stopniu totalizacji mogłyby być (przenikalnymi) instytucjami totalnymi. Warto

5 J. Rokicki, Szkoła jako instytucja totalna, [w:] Manipulacja. Pedagogiczno-społeczne aspekty cz. 1, red. J. Aksman, Kraków 2010, s. 130.

6 I. Fudali, op. cit., s. 111.

7 J. Rokicki, op. cit., s. 130. 
pamiętać, że określenie organizacji instytucją totalną nie jest infamią, ponieważ pełnią one wiele pozytywnych funkcji, dzięki którym ludzie realizują swoje potrzeby. Nie należy równocześnie ignorować wysokiego stopnia totalizacji — informuje on bowiem o potencjalnym niebezpieczeństwie ${ }^{8}$.

\section{Szpital psychiatryczny jako instytucja totalna}

Instytucje, których dominująca funkcja określana jest tradycyjnie jako socjalna, często zaliczane są właśnie do instytucji totalnych. Do kategorii tej zalicza się rozmaite domy opieki i pomocy społecznej, domy dziecka, domy starców, hospicja itp. Wydaje się jednak, że katalog ten można i należałoby poszerzyć między innymi o szpitale, a przynajmniej niektóre ich rodzaje ${ }^{9}$. W tym miejscu warto zapytać: czy istnieją rzeczywiście podstawy, by na przykład szpital psychiatryczny wciąż uznawać za instytucję totalną? W koncepcji instytucji totalnej (asylum) Ervinga Goffmana oraz koncepcji instytucji panoptycznej (panopticon) Michela Foucaulta ${ }^{10}$ jako charakterystyczne realizacje tych form pojawiają się nie szpitale w ogóle, ale konkretnie szpitale psychiatryczne (a także koszary, szkoły, zakony, więzienia itp.). Szpital jako miejsce, w którym przebywają osoby chore (upośledzone w zakresie realizacji swych ról społecznych), z założenia, w sposób dyskursywnie oczywisty i niepodważalny, nie jest miejscem codziennych czynności: ani zabawy, ani pracy. Jest rzeczywistością wyalienowaną ze społecznej codzienności, wyrwaną ze społecznego kontekstu. W szczególności uwidacznia się to w przypadku szpitala psychiatrycznego. Instytucja totalna, za jaką uznaje się szpital (zwłaszcza psychiatryczny), legitymizuje swą totalność poprzez odwołanie się do dyskursu medycyny i profesjonalnego dyskursu zawodów medycznych. Głębiej znajduje się oczywiście społeczny konstrukt zdrowia jako warunku sprawnego funkcjonowania systemu. Legitymizacja ta sięga bardzo daleko. Zanegowane zostają bowiem wartości konstruowane jako podstawowe dla współczesnych społeczeństw i współczesnego człowieka: indywidualizm i wolna wola ${ }^{11}$.

Władza w każdym szpitalu, a więc i psychiatrycznym, jak w każdej instytucji totalnej, ma charakter grupowy i wynika z miejsca, które dana osoba zajmuje w hierarchii instytucji. Generalnie jednak to personel jest zasadniczym wykonawcą i egzekutorem licznych praw regulujących funkcjonowanie instytucji jako

8 Ł. Posłuszny, Instytucje totalne dzisiaj: stan badań, krytyka, rekonfiguracje, „Studia Socjologiczne" 2017, nr 4, s. 139.

${ }^{9}$ K. Stasiuk-Krajewska, Szpital jako instytucja totalna - dyskursywne i instytucjonalne uwarunkowania komunikacji, „Dziennikarstwo i Media” 2014, nr 5, s. 162.

10 E. Goffman, Instytucje totalne. O pacjentach szpitali psychiatrycznych i mieszkańcach innych instytucji totalnych, przeł. O Waśkiewicz, J. Łaszcz, Gdańsk 2011; M. Foucault, Nadzorować i karać, przeł. T. Komendant, Warszawa 1998.

11 K. Stasiuk-Krajewska, op. cit., s. 175. 
takiej. Różnorakie napiętnowania uzasadniane są dyskursywnie — regulaminem, zasadami, wreszcie dobrem pacjenta lub współpacjentów. W tym sensie personel jest dysponentem władzy, którą ma instytucja totalna jako taka, a której legitymizacja bierze się z dyskursów, do jakich się odwołuje (w tym przypadku dyskursu medycyny i zdrowia). W rzeczywistości szpitalnej można ponadto zaobserwować wszystkie techniki adaptacyjne, które w kontekście instytucji totalnych są opisywane: wycofanie (apatię, regres, otępienie), bunt, zadomowienie (utożsamienie się z instytucją, zinternalizowanie jej norm w formie budowania w zgodzie z nimi bezpiecznej i stabilnej egzystencji), wreszcie konwersję (całkowite przejęcie norm i stanie się ich rzecznikiem). Można zatem rzec, że szpital psychiatryczny jest jednym z modelowych przykładów instytucji totalnej. Ze swoją hierarchiczną strukturą personelu, przysługującymi mu uprawnieniami penalizacyjnymi, systemem nagród i kar, intensywną, przynajmniej na początku, socjalizacją do roli pacjenta, procedurami inicjacyjnymi, izolacją przestrzenną jego członków od społeczeństwa i świata zewnętrznego czy też wypracowywanymi przez pacjentów mechanizmami wtórnego przystosowania, spełnia wszystkie cechy definicyjne Goffmanowskiego typu idealnego ${ }^{12}$.

Dokonując analizy funkcjonowania szpitala psychiatrycznego jako instytucji totalnej, Goffman zauważył, że istnieją w tej organizacji trzy rodzaje oddziaływań mających na celu zachowanie wewnętrznej dyscypliny. Pierwszy ich rodzaj to tak zwany stripping. Jest to obnażanie pacjentów poprzez odbieranie im ubrań prywatnych i nakazanie noszenia takich samych piżam, nadawanie numerów identyfikacyjnych, żądanie przekazywania informacji o życiu intymnym, obowiązek uzyskania zgody na wszelkie działania, nawet te najbardziej podstawowe, na przykład wysłanie prywatnego listu. Goffman podkreśla, że działania te zmierzają do tego, aby z pamięci pacjenta usunąć jego dawną tożsamość. Drugi rodzaj oddziaływań to kontrola środków, które posiada pacjent, oraz władza nad wszystkimi informacjami dotyczącymi pacjenta oraz samego szpitala. I wreszcie trzeci rodzaj oddziaływań, polegający na tym, że ogranicza się ruchliwość chorego - nie może on opuszczać szpitala czy oddziału ${ }^{13}$. Koncepcję Goffmana analizowało wielu naukowców, między innymi Piotr Sztompka, który dochodzi do

12 A. Miller, Szpital jako instytucja totalna. Socjologiczne studium przypadku, Warszawa 2013, s. 196. Miller podkreśla, że; „Pisząc o szpitalu, o sytuacjach, których byłem uczestnikiem, o osobach, które znałem, dokonując na podstawie posiadanej wiedzy teoretycznej określonych interpretacji, dane mi było zrozumieć wiele zagadnień dotyczących mojego pobytu na dwóch szpitalnych oddziałach. Pewne obserwacje, spostrzeżenia, początkowo niejasne, niezrozumiałe, po głębszej eksploracji, dłuższym zastanowieniu zaczęły się wpisywać w pewien racjonalny, przemyślany schemat — tak jakby w instytucji nic nie działo się przypadkowo. Dzięki temu mogłem z innej perspektywy spojrzeć na status pacjenta szpitala psychiatrycznego, jaki miałem przez łącznie osiemdziesiąt dni. Status początkowo wstydliwy, wymagający bardziej ukrycia niż ujawniania, z czasem zaakceptowany, równocześnie traktowany jako symbol epizodu życiowego, a nie ewentualnej stygmatyzacji".

13 E. Goffman, op. cit., s. 14-15. 
wniosku, że totalność instytucji szpitala psychiatrycznego prowadzi do wycofania emocjonalnego pacjentów, co powoduje w konsekwencji destrukcję ich tożsamości $^{14}$. To bardzo mocne stwierdzenie i daleko idący wniosek. Instytucję totalną na przykładzie szpitala psychiatrycznego opisuje także Jerzy Krzysztoń w powieści Obłęd, w której można przeczytać: „Tu się nie zagląda w kalendarz, bo i po co? Czas się kończy, nie zaczyna. My nie wiemy, który dzień jest który" ${ }^{15}$. Krzysztoń podkreśla szpitalną rutynę, w której dni są do siebie bardzo podobne, w zasadzie nie różnią się od siebie, codziennie odbywa się bowiem „to samo i w tym samym rytmie, pobudki, toaleta, zastrzyki, śniadanie, leki, sprzątanie, obiad, leki, kolacja i spać"16.

Wskazać też trzeba, że podejmowane są próby „odtotalizowania” szpitala psychiatrycznego, Jak podkreśla Błażej Kmieciak, w latach sześćdziesiątych XX wieku zaczął się rozwijać nurt antypsychiatrii. Jego zasadniczym założeniem była dekonstrukcja choroby psychicznej i wykazanie, że jest ona faktycznie wymysłem psychiatrów. Nurt ten wywarł znaczący wpływ na amerykańską, ale także europejską psychiatrię i zapoczątkował konkretne zmiany systemowe. Zaczęto odchodzić od utrzymywania dużych szpitali psychiatrycznych, określając je jako fabryki obłędu. Poza tym coraz częściej zaczęto sięgać do metody społeczności terapeutycznych. Model ten wprowadzono do psychiatrii w latach czterdziestych ubiegłego wieku, a jego celem jest w szczególności „kształtowanie pozytywnych wzorców zachowań". Tutaj pacjent współdecyduje o leczeniu, organizacji oddziału itp. Akcentuje się, że ta metoda stanowi formę pośrednią pomiędzy tradycyjną terapią psychiatryczną a życiem w środowisku otwartym ${ }^{17}$.

Koncepcja instytucji totalnej z jednej strony i koncepcja społeczności terapeutycznej z drugiej pokazują, że szpital psychiatryczny charakteryzuje się dynamiką środowiska. Goffman ukazał szpital psychiatryczny w sposób budzący niepokój odnośnie do jego funkcjonowania; z kolei metoda społeczności terapeutycznej daje określoną szansę na „odtotalizowanie” tej instytucji. Życie w grupie, pokazane przez Goffmana jako wada, w drugiej wspomnianej metodzie zyskuje walor terapeutyczny. Oczywiście metoda społeczności terapeutycznej nie jest w stanie spowodować, że już nie będzie się postrzegać szpitala jako instytucji totalnej $^{18}$, ale może pozwolić na odejście od jego obrazu jako instytucji totalnej sensu stricto na rzecz określania go mianem instytucji quasi-totalnej.

14 P. Sztompka, Socjologia. Analiza społeczeństwa, Kraków 2003, s. 77.

15 Zob. J. Krzysztoń, Obłęd, Warszawa 1980, t. 2, s. 339. Jest to autobiograficzna powieść, której bohater cierpi na schizofrenię, ukazała się już po samobójczej śmierci autora i — jak się podkreśla - jest jego najlepszym dziełem. Autor pisał ją, lecząc się w szpitalu psychiatrycznym.

16 Patrz: E. Tarkowska, Socjolog w instytucji totalnej. Uwagi na marginesie badań, „Kultura i Społeczeństwo" 1996, nr 1, s. 26.

17 B. Kmieciak, Czy szpital psychiatryczny jest (nadal) instytucją totalną?, „Psychiatria i Psychologia Kliniczna" 17, 2017, nr 2, s. 146.

18 Ibidem, s. 147. 


\section{Podsumowanie}

W mojej opinii elementy totalizacji nie są w szpitalach psychiatrycznych tak jednoznaczne lub tak drastyczne, jak w typowych instytucjach totalnych — dlatego lepiej szpital taki określać mianem instytucji quasi-totalnej ${ }^{19}$ zamiast zaliczać go do instytucji stricte totalnych. Wydaje się, że to określenie jest bardziej trafne. Możemy mówić o instytucjach totalnych sensu stricto, czyli takich, które mają wszystkie wymienione cechy, ale są też instytucje wykazujące tylko określone cechy instytucji totalnej ${ }^{20}$. W przypadku instytucji, jaką jest szpital psychiatryczny, możemy wskazać niewątpliwie na pewne cechy instytucji totalnej, ale określanie go instytucją totalną sensu stricto wydaje się być zbyt pochopne.

Powyższe rozważania można podsumować stwierdzeniem, że choć szpital psychiatryczny ma pewne cechy instytucji totalnej, to przecież jego celem nadrzędnym jest pomoc pacjentowi, a nie zdominowanie go i przejęcie nad nim władzy. Słuszne wydaje mi się określenie, że w przypadku lekarzy psychiatrów dostrzec można podejście tak zwanego miękkiego paternalizmu. Oznacza to, że ingerencje medyczne bez zgody pacjenta wykonywane są tylko w ostateczności i z uwagi na spodziewane korzyści, które mogą przynieść konkretnemu chore$\mathrm{mu}$, niezdolnemu do racjonalnej oceny ze względu na stan swojego zdrowia ${ }^{21}$. Psychiatria niewątpliwie jest specjalnością medyczną o charakterze szczególnym, gdzie przymus fizyczny przeplata się z działaniem dla dobra pacjenta. Nadal słyszymy opinie, że szpital psychiatryczny to instytucja totalna, ale wydaje się, że jej funkcjonowanie współcześnie, zwłaszcza z wykorzystaniem metody społeczności terapeutycznej, może nieco złagodzić ten obraz. To oczywiście nadal nie rozwiązuje problemu. Szpital, owszem, był, jest i pewnie będzie nazywany instytucją totalną, niezależnie od tego, jak negatywne skojarzenia może budzić to słowo. Mimo to jest też, jak słusznie podkreśla Adam Miller, kolejną z wielu instytucji państwowej interwencji w określone obszary życia społecznego. Ma więc pełnić określone funkcje, jakie w tym przypadku należy określić mianem leczniczo-terapeutycznych. Szpital psychiatryczny w takim kształcie, w jakim istnieje współcześnie, jest nie po to, by karać, ale żeby przywracać chorych do społeczeństwa. Oczywiście można zastanawiać się, czy nie ma może lepszych, przynoszących korzystniejsze rezultaty, a jednocześnie stanowiących mniejszą ingerencję w sferę praw i wolności jednostki sposobów osiągania tego celu ${ }^{22}$. Warto rozważyć, czy nie bardziej niebezpieczne jest jednak stygmatyzowanie osób chorych psychicznie aniżeli traktowanie szpitala psychiatrycznego jako instytucji totalnej. Pytanie to - ciekawe, ale rodzące kolejne problemy — wykracza jednak poza ramy niniejszego tekstu.

19 K. Stasiuk-Krajewska, op. cit., s. 177.

20 M. Kępiński, Antropologiczne studium instytucji o charakterze totalnym, „Kultura i Historia” 2002 , nr 2, s. 88 .

21 B. Kmieciak, op. cit., s. 149.

22 A. Miller, op. cit., s. 197-198. 


\section{Bibliografia}

Baranowska A., Proces ksztaltowania się tożsamości instytucji totalnej na przykładzie żolnierzy mieszkańców obozu Babilon w Iraku, [w:] Tożsamość spoleczna grup dyspozycyjnych, red. J. Maciejewski, W. Nowosielski, Wrocław 2009.

Foucault M., Nadzorować i karać, przeł. T. Komendant, Warszawa 1998.

Fudali I., Instytucje totalne — jak myśla instytucje w zglobalizowanym społeczeństwie, „Drohiczyński Przegląd Naukowy, Wielokulturowe Studia Drohiczyńskiego Towarzystwa Naukowego" 2017, nr 9.

Goffman E., Charakterystyka instytucji totalnych, [w:] Elementy teorii socjologicznych, red. W. Derczyński, A. Jasińska-Kania, J. Szacki, Warszawa 1975.

Goffman E., Instytucje totalne. O pacjentach szpitali psychiatrycznych i mieszkańcach innych instytucji totalnych, przeł. O Waśkiewicz, J. Łaszcz, Gdańsk 2011.

Kępiński M., Antropologiczne studium instytucji o charakterze totalnym, „Kultura i Historia” 2002, nr 2.

Kmieciak B., Czy szpital psychiatryczny jest (nadal) instytucją totalna?, „Psychiatria i Psychologia Kliniczna" 17, 2017, nr 2.

Krzysztoń J., Obłęd, Warszawa 1980.

Miller, A. Szpital jako instytucja totalna. Socjologiczne studium przypadku, Warszawa 2013.

Posłuszny Ł., Instytucje totalne dzisiaj: stan badań, krytyka, rekonfiguracje, „Studia Socjologiczne” 2017, $\mathrm{nr} 4$.

Rokicki J., Szkoła jako instytucja totalna, [w:] Manipulacja. Pedagogiczno-społeczne aspekty cz. 1, red. J. Aksman, Kraków 2010.

Sobkowiak M., Przemoc instytucjonalna w jednostkach organizacyjnych pomocy społecznej, Szczecin 2012.

Stasiuk-Krajewska K., Szpital jako instytucja totalna - dyskursywne i instytucjonalne uwarunkowania komunikacji, „Dziennikarstwo i Media” 2014, nr 5.

Sztompka P., Socjologia. Analiza społeczeństwa, Kraków 2003.

Tarkowska E., Socjolog w instytucji totalnej. Uwagi na marginesie badań, „Kultura i Społeczeństwo" 1996, nr 1. 